ISSN 0258-7122 (Print), 2408-8293 (Online)

Bangladesh J. Agril. Res. 41(3): 565-577, September 2016

\title{
COMBINING ABILITY AND HETEROSIS ON YIELD AND ITS COMPONENT TRAITS IN MAIZE (Zea mays L.)
}

\author{
M. Z. A. TALUKDER ${ }^{1}$, A. N. M. S. KARIM ${ }^{2}$ \\ S. AHMED ${ }^{3}$ AND M. AMIRUZZAMAN ${ }^{4}$
}

\begin{abstract}
Combining ability and heterosis were studied in a $7 \times 7$ half diallel cross in maize for grain yield and yield contributing characters. Significant general and specific combining ability variances were observed for all the characters studied. The significant estimates of GCA and SCA variances suggested the importance of both additive and non-additive gene actions for the expression studied traits. In these studies, variances due to SCA were higher than GCA for all charactesr, which revealed the predominance of non additive gene action (dominance and epistasis) for controlling these traits. Parents $\mathrm{P}_{1}$ and $\mathrm{P}_{4}$ were excellent general combiner for days to tasseling and silking while $\mathrm{P}_{1}$ and $\mathrm{P}_{5}$ for early maturity. $\mathrm{P}_{4}$ for short height and, $\mathrm{P}_{4}$ and $\mathrm{P}_{7}$ for higher thousand kernel weight. The parents $\mathrm{P}_{4}$ and $\mathrm{P}_{6}$ having good combining abilities for yield. Heterosis estimation was carried out using two commercial varieties NK40 and 900MG. When standard commercial check NK40 was used, the percent heterosis for kernel yield varied from -51.39 to $12.53 \%$. Among the $21 \mathrm{~F}_{1} \mathrm{~s}$, 3crosses exhibited significant positive heterosis for kernel yield. The highest heterosis was exhibited by the cross $\mathrm{P}_{4} \times \mathrm{P}_{6}(12.43 \%), \quad \mathrm{P}_{6} \times \mathrm{P}_{7}(10.89 \%)$ and $\mathrm{P}_{2} \times \mathrm{P}_{3}(9.87 \%)$ respectively. Compared with $900 \mathrm{MG}$ as check, the percent heterosis for kernel yield varied from -53.73 to $7.01 \%$. Among the $21 \mathrm{~F}_{1} \mathrm{~s}$, none of the crosses exhibited significant positive heterosis for kernel yield. The highest heterosis were exhibited by the crosses $\mathrm{P}_{4} \times \mathrm{P}_{6}(7.01 \%), \mathrm{P}_{6} \times \mathrm{P}_{7}(5.55 \%)$ and $\mathrm{P}_{2} \times \mathrm{P}_{3}(4.57 \%)$. The crosses showed significant positive SCA values could be used for variety development after verifying them across the agro-ecological zones of Bangladesh.
\end{abstract}

Keywords: Combining ability, heterosis, GCA, SCA, maize (Zea mays L.), nature of gene action.

\section{Introduction}

Maize is becoming an important crop in the rice based cropping system. Maize continues to expand rapidly at an average rate of $20 \%$ year $^{-1}$ (CIMMYT, 2008). A combination of high market demand with comparatively low cost of production and high yield has generated tremendous interest among the farmers in maize cultivation. The estimated average national grain yield is $5.7 \mathrm{t} \mathrm{ha}^{-1}$, is the highest in Asia, and that compares with average on-farm grain yield of

\footnotetext{
${ }^{1}$ Senior Scientific Officer, Plant Breeding Division, Bangladesh Agricultural Research Institute (BARI), Gazipur, ${ }^{2}$ Scientific Officer, Plant Breeding Division, BARI, Gazipur, ${ }^{3 \& 4}$ Principal Scientific Officer, Plant Breeding Division, BARI, Gazipur, Bangladesh.
} 
around $2 \mathrm{t} \mathrm{ha}^{-1}$ for wheat or 3-4 $\mathrm{t} \mathrm{ha}^{-1}$ with boro rice (CIMMYT, 2008). Day by day it is gaining popularity in the country due to huge demand, particularly for poultry feed industry. The acreage and production of maize have an increasing tendency with the introduction of exotic hybrids due to high yield potentials. The farmers are mostly cultivating imported hybrid maize, but they are very expensive. The local hybrids are cheap and farmers can get it easily.

Combining ability estimation are important genetic attributes for maize breeders in anticipating improvement in productivity via hybridization and selection. Maize exhibits heterosis for all traits and the extent of heterosis vary significantly depending on the choice of parents and the trait(s) measured. Maize unveiled excessive ability for heterotic expression, even several inbred lines exhibit enough variability to find out appropriate genotypes for a successful breeding program and generating stable inbred lines for production of commercial hybrids. Genetic variability and harboring of excessive hybrid vigour makes maize as a model crop for all kind of studies. Furthermore, the input cost of hybrids can easily be minimized by avoiding losses of resources and time in production of desirable inbred lines, as it is obvious that the breeding community always preferred hybrid maize rather than Open pollinated variety (OPV) or synthetic variety because of its high productivity. Combining ability studies provide information on the genetic mechanisms controlling the inheritance of quantitative traits and enable the breeders to select suitable parents for further improvement or use in hybrid breeding for commercial purposes. In biometrical genetics two types of combining abilities are considered i.e. general combining ability (GCA) and specific combining ability (SCA). General combining ability refers to the average performance of the genotype in a series of hybrid combinations and is a measure of additive gene action whereas; specific combining ability is the performance of a parent in a specific cross in relation to general combining ability (Sharief et al., 2009). Combining ability analysis is of special importance in cross pollinated crops as it helps in identifying potential inbred parents that can be used for producing hybrids. Such studies also help in elucidating the nature and magnitude of different types of gene action governing the expression of quantitative characters of economic importance (Pal and Prodhan, 1994).

Inbred lines are pre-requisite for hybrid development in maize. Combining ability analysis is of special importance in cross-pollinated crops like maize as it helps in identifying potential parents that can be used for producing hybrids and synthetics (Vasal, 1998). The nature and magnitude of gene action is an important factor in developing an effective breeding program, which can be understood through combining ability analysis. This information is helpful to plant breeders for formulating hybrid breeding program.

Heterosis and combining ability are prerequisites for developing a good economically viable maize variety. Information on the heterotic patterns and 
combing ability among maize germplasm is essential in maximizing the effectiveness of hybrid development (Beck et al., 1990). The phenomenon of heterosis has been exploited extensively in crop breeding, leading to significant increase in yield. Heterosis is used to describe this phenomenon when the parents are taken from different populations of the same species; hybrid vigor is used when the parents are taken from different species (Charlesworth and Willis, 2009).

Therefore, the present investigation with $7 \times 7$ half diallel cross was undertaken for isolating superior inbred lines and thereby to identify better combining parents to obtain suitable hybrids and determine percent of heterosis using standard commercial checks.

\section{Materials and Method}

Seven diverse maize inbred lines viz. $\mathrm{P}_{1}$ (BIL 79), $\mathrm{P}_{2}$ (BIL 31), $\mathrm{P}_{3}$ (CML 468-2B), $\mathrm{P}_{4}$ (CA03130-1-2-B-B-B), $\mathrm{P}_{5}$ (CML 481-1-B), $\mathrm{P}_{6}$ (CML 20-2-B) and $\mathrm{P}_{7}$ (CML 487-2-B) were crossed in a diallel fashion excluding the reciprocals during the rabi season in 2012-13. The resulting $21 \mathrm{~F}_{1}$ 's and their 7 parents were evaluated along with three checks (BARI hybrid maize 9, NK40 and 900MG) in a alpha lattice design with two replications at BARI, Gazipur in the following rabi season of 2013-2014. Each entry planted in one rows of $5 \mathrm{~m}$ long plot. The spacing between rows was $75 \mathrm{~cm}$ and plant to plant distance was $20 \mathrm{~cm}$. One plant per hill was maintained after proper thinning. Data were recorded on ten randomly selected plants from each plot for plant height $(\mathrm{cm})$, ear height $(\mathrm{cm})$, days to tasseling and silking, days to maturity, yield and 1000 kernel weight. Kernel yield was recorded on whole plot basis and finally converted to t/ha.

Data were analyzed for variance for all the characters studied. The mean performances of all characters were analyzed using Crop Stat software. General combining ability (GCA) and specific combining ability (SCA) were estimated following Model I, Method II of Griffing (1956). The mean squares for GCA and SCA were tested against error variance desired using the mean data of all the single cross hybrids and check variety, was estimated and tested according to Singh and Singh (1994). Percent heterosis was calculated by using the following formula:

Standard heterosis $(\%)=\left[\left(\overline{F_{1}}-\overline{C V}\right) / \overline{C V}\right] \times 100$

Where, $\bar{F}_{1}$ and $\overline{C V}$ represented the mean performance of hybrid and standard check variety. The significance test for heterosis was done by using standard error of the value of check variety. 


\section{Results and Discussion}

The mean performances of all the crosses along with the checks are presented in Table 1. Significant differences were observed for all the characters except days to maturity and 1000 kernel weight, indicating sufficient genetic variability present among the materials.

Table 1. Mean performance of hybrid maize obtained from $7 \times 7$ half diallel crosses of maize evaluated at Gazipur during rabi 2013-2014.

\begin{tabular}{|c|c|c|c|c|c|c|c|}
\hline $\begin{array}{l}\text { Cross/ } \\
\text { Hybrids }\end{array}$ & $\begin{array}{c}\text { Days to } \\
\text { tassel }\end{array}$ & $\begin{array}{l}\text { Days to } \\
\text { silk }\end{array}$ & $\begin{array}{l}\text { Plant ht. } \\
(\mathrm{cm})\end{array}$ & $\begin{array}{c}\text { Ear ht. } \\
(\mathrm{cm})\end{array}$ & $\begin{array}{l}\text { Days to } \\
\text { maturity }\end{array}$ & $1000 \mathrm{kw}$ & $\begin{array}{l}\text { Yield } \\
(\mathrm{t} / \mathrm{h})\end{array}$ \\
\hline $\mathrm{P}_{1} \times \mathrm{P}_{2}$ & 95 & 98 & 196 & 96 & 148 & 310 & 10.09 \\
\hline $\mathrm{P}_{1} \times \mathrm{P}_{3}$ & 93 & 96 & 202 & 90 & 144 & 300 & 6.75 \\
\hline $\mathrm{P}_{1} \times \mathrm{P}_{4}$ & 86 & 89 & 183 & 99 & 144 & 340 & 7.67 \\
\hline $\mathrm{P}_{1} \times \mathrm{P}_{5}$ & 95 & 99 & 191 & 99 & 144 & 250 & 4.65 \\
\hline $\mathrm{P}_{1} \times \mathrm{P}_{6}$ & 96 & 100 & 215 & 106 & 148 & 305 & 7.59 \\
\hline $\mathrm{P}_{1} \times \mathrm{P}_{7}$ & 94 & 98 & 200 & 103 & 149 & 295 & 6.73 \\
\hline $\mathrm{P}_{2} \times \mathrm{P}_{3}$ & 93 & 96 & 228 & 112 & 147 & 300 & 10.51 \\
\hline $\mathrm{P}_{2} \times \mathrm{P}_{4}$ & 85 & 88 & 178 & 94 & 145 & 360 & 8.46 \\
\hline $\mathrm{P}_{2} \times \mathrm{P}_{5}$ & 94 & 97 & 229 & 112 & 149 & 325 & 7.35 \\
\hline $\mathrm{P}_{2} \times \mathrm{P}_{6}$ & 95 & 99 & 204 & 104 & 149 & 355 & 9.22 \\
\hline $\mathrm{P}_{2} \times \mathrm{P}_{7}$ & 102 & 107 & 182 & 91 & 149 & 380 & 4.71 \\
\hline $\mathrm{P}_{3} \times \mathrm{P}_{4}$ & 85 & 88 & 208 & 91 & 144 & 360 & 8.94 \\
\hline $\mathrm{P}_{3} \times \mathrm{P}_{5}$ & 93 & 97 & 232 & 110 & 145 & 235 & 6.63 \\
\hline $\mathrm{P}_{3} \times \mathrm{P}_{6}$ & 94 & 98 & 192 & 100 & 148 & 290 & 10.07 \\
\hline $\mathrm{P}_{3} \times \mathrm{P}_{7}$ & 89 & 93 & 211 & 103 & 143 & 280 & 7.30 \\
\hline $\mathrm{P}_{4} \times \mathrm{P}_{5}$ & 90 & 94 & 212 & 107 & 142 & 360 & 8.70 \\
\hline $\mathrm{P}_{4} \times \mathrm{P}_{6}$ & 87 & 91 & 180 & 104 & 145 & 360 & 10.76 \\
\hline $\mathrm{P}_{4} \times \mathrm{P}_{7}$ & 90 & 94 & 215 & 99 & 146 & 330 & 8.67 \\
\hline $\mathrm{P}_{5} \times \mathrm{P}_{6}$ & 96 & 100 & 185 & 101 & 148 & 310 & 8.74 \\
\hline $\mathrm{P}_{5} \times \mathrm{P}_{7}$ & 92 & 94 & 201 & 107 & 145 & 295 & 7.78 \\
\hline $\mathrm{P}_{6} \times \mathrm{P}_{7}$ & 93 & 97 & 183 & 98 & 149 & 300 & 10.61 \\
\hline BHM9 & 94 & 97 & 198 & 107 & 145 & 305 & 8.33 \\
\hline NK 40 & 89 & 92 & 210 & 100 & 146 & 415 & 9.57 \\
\hline $900 \mathrm{MG}$ & 91 & 95 & 202 & 106 & 149 & 370 & 10.05 \\
\hline F-test & $* *$ & $* *$ & $* *$ & $* *$ & - & - & *** \\
\hline $\mathrm{CV}(\%)$ & 2.5 & 2.8 & 10.4 & 9.8 & 2.3 & 20.4 & 11.5 \\
\hline $\operatorname{LSD}_{(5 \%)}$ & 3.74 & 4.08 & 26.08 & 15.7 & 5.4 & 129.80 & 1.84 \\
\hline
\end{tabular}

$*, * *$ indicated at $5 \%$ and $1 \%$ level of significance, $\mathrm{KW}=$ Kernel Weight. 
The magnitude of mean squares for general and specific combining abilities for studied characters indicated significant differences among the GCA as well as SCA effects. This suggested presence of notable genetic variability among the genotypes for the characters studied. Furthermore, the analysis of variance for combining abilities (GCA and SCA) showed significant variations for all the characters except GCA of 1000 kernel weight, which indicate significant differences among the GCA as well as SCA effects. Highly significant differences for most of the sources of variation were also reported by Narro et al. (2003). The significant differences for gca and sca variances for different traits in maize have been reported earlier (Mathur and Bhatnagar, 1995). The mean squares of genotypes (diallel hybrids) were highly significant for all the traits. This indicated an adequate amount of variability present in the materials for these traits. Further, analysis of variance for combining ability showed that estimates of mean squares due to GCA and SCA were highly significant for all the characters. This indicated importance of both additive and non-additive components of genetic variance in controlling these traits. This was confirmed by Debnath and Sarker (1990) and Derera et al., (2007) who reported similar results for yield and yield components in maize. Importannce of both additive and nonadditive gene effects in maize were also reported by Rokadia and Kaushik (2005).

Table 2. Mean squares due to general and specific combining ability (GCA and SCA) for 7 characters in a $7 \times 7$ diallel cross of maize

\begin{tabular}{l|c|c|c|c|c|c|c|c}
\hline \multirow{2}{*}{$\begin{array}{c}\text { Sources of } \\
\text { variation }\end{array}$} & df & \multicolumn{7}{|c}{ Mean of squares } \\
\cline { 3 - 10 } & & $\begin{array}{c}\text { Days to } \\
\text { tassel }\end{array}$ & $\begin{array}{c}\text { Days to } \\
\text { silk }\end{array}$ & $\begin{array}{c}\text { Plant ht. } \\
(\mathrm{cm})\end{array}$ & $\begin{array}{c}\text { Ear ht. } \\
(\mathrm{cm})\end{array}$ & $\begin{array}{c}\text { Days to } \\
\text { maturity }\end{array}$ & $\begin{array}{c}1000-\mathrm{KW} \\
(\mathrm{g})\end{array}$ & $\begin{array}{c}\text { Yield } \\
(\mathrm{t} / \mathrm{h})\end{array}$ \\
\hline Genotype & 27 & $41.22^{* *}$ & $49.83^{* *}$ & $1631.83^{* *}$ & $767.05^{* *}$ & $43.29^{* *}$ & $7690.14^{*}$ & $11.10^{* *}$ \\
GCA & 6 & $38.12^{* *}$ & $38.88^{* *}$ & $905.27^{*}$ & $309.48^{* *}$ & $33.997^{* *}$ & 3971.16 & $5.67^{* *}$ \\
SCA & 21 & $43.15^{* *}$ & $52.96^{* *}$ & $1839.43^{* *}$ & $897.78^{* *}$ & $45.95^{* *}$ & $8752.71^{*}$ & $12.65^{* *}$ \\
Error & 27 & 2.03 & 2.74 & 260.16 & 81.88 & 6.34 & 3197.55 & 0.78 \\
GCA: & & 0.88 & 0.73 & 0.49 & 0.34 & 0.74 & 0.45 & 0.45 \\
SCA & & & & & & & & \\
\hline
\end{tabular}

In these studies, variances due to SCA were higher than GCA for all character, which revealed the predominance of non additive gene action (dominance and epistasis) for controlling these traits. Predominant role of SCA effect i.e. nonadditive gene actions in the inheritance of kernel yield was also reported by several workers (Khotyleva et al., 1986, Zelleke, 2000, Lee, 1987 and Singh and Kumar, 2008). The genetic control of different yield contributing characters is finally projected through kernel yield. Therefore, non-additive gene action for kernel yield is expected. 


\section{General combining ability (GCA) effects}

The estimates of general combining ability effects of the parents are presented in Table 3. For days to tasseling and silking, negative estimates are considered desirable as those were observed to be associated with earliness. The parents $\mathrm{P}_{1}$ and $\mathrm{P}_{4}$ showed negative GCA effects for this trait. In case of plant height and ear height, negative estimates are desirable since they are correlated with shorter plant height. Parent $\mathrm{P}_{4}$ was good combiner having significant negative GCA effects both for plant and ear height. According to Singh and Singh (1979), generally earliness is associated with days to silk and the shorter plants with low ear height are associated with resistance to lodging.

Parents $\mathrm{P}_{4}$ and $\mathrm{P}_{6}$ were the best general combiner for yield and also possessed significant positive gca effect. This was supported by Singh et al., (1995) and Hussain et al., (2003). From the GCA effect it was observed that, none of the parents individually showed good general combiner for all the yield component.

The overall study of GCA effects suggests that parents $\mathrm{P}_{1}$ and $\mathrm{P}_{4}$ were excellent general combiner for early tasseling and silking, parents $P_{1}$ and $P_{5}$ were excellent for early maturity and parents $\mathrm{P}_{4}$ for short height, parents $\mathrm{P}_{4}$ and $\mathrm{P}_{6}$ for yield. These parents could be used in future breeding program to improve maize yield with desirable traits.

\section{Specific combining ability (SCA) effects}

The SCA effects of the crosses for seven characters are presented in Table 4. For days to $50 \%$ tasseling, 5 crosses exhibited significant negative sca effects and for days to $50 \%$ silking 5 crosses showed significant negative SCA, indicates early flowering of the hybrids. The SCA effect of the cross $\mathrm{P} 4 \times \mathrm{P} 5$ was positive significant indicating for higher 1000 kernel weight.

For considering yield, among 21 hybrids 8 crosses performed significant positive SCA effects for kernel yield (Table 4) and most of them also possessed high mean values for the same trait (Table 1). Out of 21 crosses eight viz. $\mathrm{P}_{1} \times \mathrm{P}_{2}$, $\mathrm{P}_{2} \times \mathrm{P}_{3}, \mathrm{P}_{3} \times \mathrm{P}_{6}, \mathrm{P}_{4} \times \mathrm{P}_{5}, \mathrm{P}_{4} \times \mathrm{P}_{6}, \mathrm{P}_{4} \times \mathrm{P}_{7}, \mathrm{P}_{5} \times \mathrm{P}_{7}$ and $\mathrm{P}_{6} \times \mathrm{P}_{7}$ showed significant positive SCA effects for yield. The significant positive SCA effect involved parents where one or both the parents were related to good combiners, indicating GCA of the parental lines plays a key role for high yield. Xingming et al., (2002) also drew similar conclusion. These crosses also possessed high per se performances (Table 1). Vasal (1998) also suggested to include one good combiner (especially female parent) during crossing to obtain higher heterosis. 


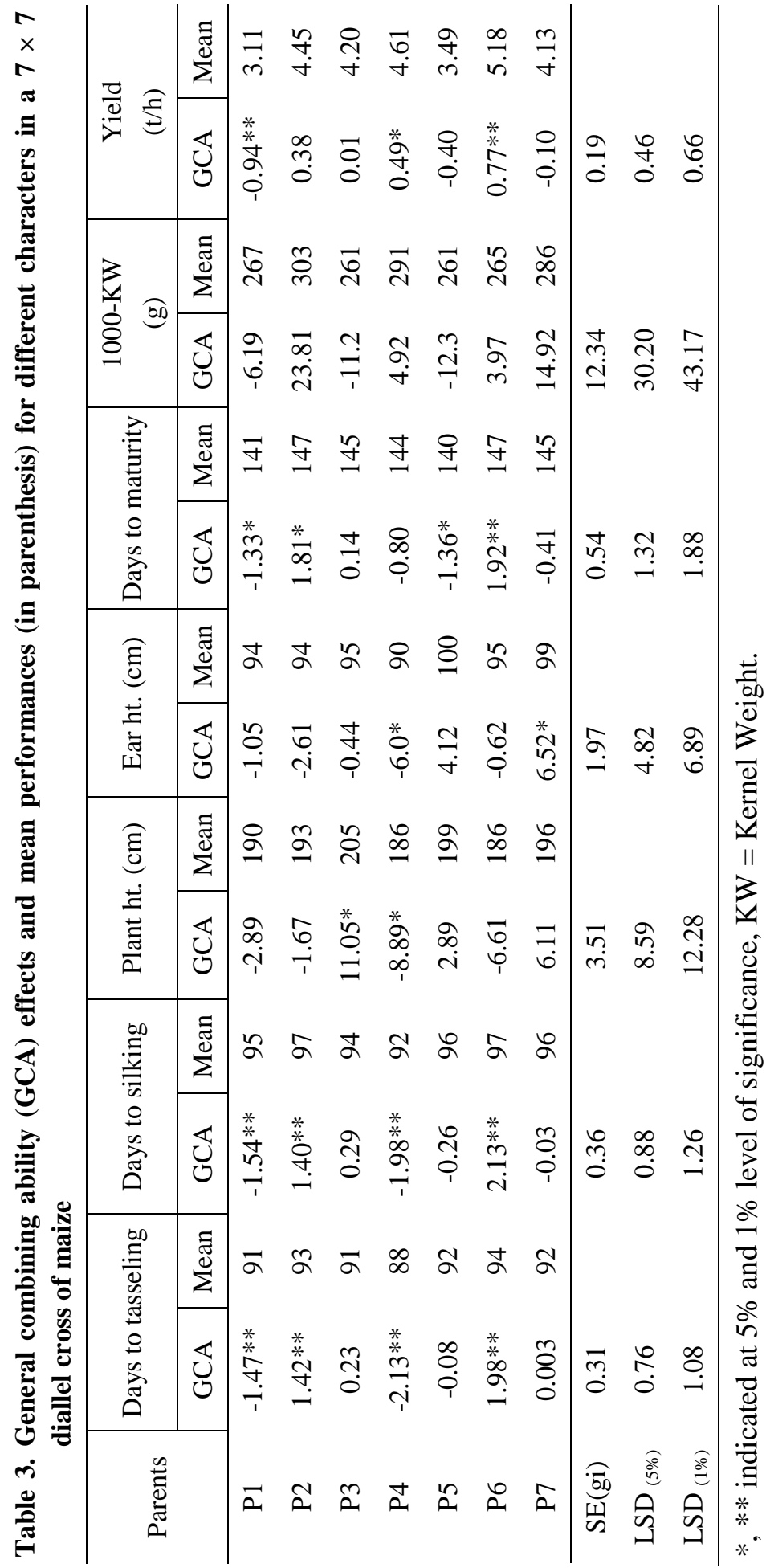


Table 4. Specific combining ability (SCA) effects for different characters in $7 \times 7$ diallel cross in maize

\begin{tabular}{|c|c|c|c|c|c|c|c|}
\hline Cross & $\begin{array}{c}\text { Days to } \\
\text { tassel }\end{array}$ & $\begin{array}{c}\text { Days to } \\
\text { silk }\end{array}$ & $\begin{array}{l}\text { Plant ht. } \\
(\mathrm{cm})\end{array}$ & $\begin{array}{l}\text { Ear ht. } \\
(\mathrm{cm})\end{array}$ & \begin{tabular}{|l|} 
Days to \\
maturity
\end{tabular} & $\begin{array}{c}1000-\mathrm{KW} \\
(\mathrm{g})\end{array}$ & Yield (t/ha) \\
\hline $\mathrm{P}_{1} \times \mathrm{P}_{2}$ & $3.08 * *$ & $3.15^{* *}$ & 12.43 & 8.23 & $3.65^{*}$ & 7.92 & $3.46 * *$ \\
\hline $\mathrm{P}_{1} \times \mathrm{P}_{3}$ & $2.25^{*}$ & $2.26^{*}$ & 5.71 & -0.44 & 1.31 & 32.92 & 0.50 \\
\hline $\mathrm{P}_{1} \times \mathrm{P}_{4}$ & $-2.36^{*}$ & $-2.46^{*}$ & 6.65 & 14.55 & 2.26 & 56.81 & 1.11 \\
\hline $\mathrm{P}_{1} \times \mathrm{P}_{5}$ & $5.08 * *$ & $5.32 * *$ & 2.88 & 4.50 & 2.32 & -15.97 & $-1.20 * *$ \\
\hline $\mathrm{P}_{1} \times \mathrm{P}_{6}$ & $4.02 * *$ & $4.43^{* *}$ & $35.88 * *$ & 16.24 & 3.54 & 40.69 & 0.57 \\
\hline $\mathrm{P}_{1} \times \mathrm{P}_{7}$ & $3.97 * *$ & $4.10 * *$ & 8.15 & 5.59 & $6.38 * *$ & 1.81 & 0.58 \\
\hline $\mathrm{P}_{2} \times \mathrm{P}_{3}$ & -0.64 & -1.18 & $30.49 * *$ & $23.61 * *$ & 1.21 & 2.92 & $2.94 * *$ \\
\hline $\mathrm{P}_{2} \times \mathrm{P}_{4}$ & $-5.75^{* *}$ & $-6.40 * *$ & 0.43 & 10.60 & -0.35 & 46.81 & 0.58 \\
\hline $\mathrm{P}_{2} \times \mathrm{P}_{5}$ & 1.19 & 0.88 & $39.65^{* *}$ & $19.06^{* *}$ & $4.71 * *$ & 29.03 & 0.18 \\
\hline $\mathrm{P}_{2} \times \mathrm{P}_{6}$ & 0.14 & 0.48 & $23.65^{*}$ & $15.79^{*}$ & 0.93 & 60.69 & 0.89 \\
\hline $\mathrm{P}_{2} \times \mathrm{P}_{7}$ & $8.58 * *$ & $10.65^{* *}$ & -11.07 & -4.85 & $3.76^{*}$ & 56.81 & $-2.75^{* *}$ \\
\hline $\mathrm{P}_{3} \times \mathrm{P}_{4}$ & $-5.08 * *$ & $-5.79 * *$ & 17.21 & 5.93 & 0.82 & 81.81 & 1.43 \\
\hline $\mathrm{P}_{3} \times \mathrm{P}_{5}$ & 1.36 & 1.49 & $29.43^{* *}$ & $14.89^{*}$ & 2.37 & -25.97 & -0.16 \\
\hline $\mathrm{P}_{3} \times \mathrm{P}_{6}$ & -0.19 & 0.60 & -0.51 & 9.13 & 2.10 & 30.69 & $2.10^{* *}$ \\
\hline $\mathrm{P}_{3} \times \mathrm{P}_{7}$ & $-2.75^{* *}$ & $-2.24 *$ & 5.21 & 4.98 & -0.57 & -8.19 & 0.21 \\
\hline $\mathrm{P}_{4} \times \mathrm{P}_{5}$ & 0.25 & 0.76 & $29.87 * *$ & $17.38^{* *}$ & 0.32 & $82.91 *$ & $1.61 * *$ \\
\hline $\mathrm{P}_{4} \times \mathrm{P}_{6}$ & $-4.30^{* *}$ & $-4.63^{* *}$ & 7.37 & $19.01^{* *}$ & 0.04 & 4.58 & $2.49 * *$ \\
\hline $\mathrm{P}_{4} \times \mathrm{P}_{7}$ & 0.64 & 0.54 & 29.15 & 6.67 & $3.37 *$ & 25.69 & $1.26^{*}$ \\
\hline $\mathrm{P}_{5} \times \mathrm{P}_{6}$ & $2.63 * *$ & $3.15^{* *}$ & 0.60 & 6.07 & $3.60^{*}$ & 51.80 & $1.18^{*}$ \\
\hline $\mathrm{P}_{5} \times \mathrm{P}_{7}$ & 0.08 & -0.68 & 3.38 & 4.43 & -0.07 & 7.91 & 1.10 \\
\hline $\mathrm{P}_{6} \times \mathrm{P}_{7}$ & -0.47 & -0.57 & -5.13 & 0.16 & 3.15 & 14.58 & $2.76^{*}$ \\
\hline SE(ij) & 0.91 & 1.05 & 10.24 & 5.74 & 1.60 & 35.89 & 0.56 \\
\hline $\operatorname{LSD}_{(5 \%)}$ & 1.90 & 2.19 & 21.36 & 11.97 & 3.34 & 74.87 & 1.17 \\
\hline $\operatorname{LSD}_{(1 \%)}$ & 2.59 & 2.99 & 29.13 & 16.33 & 4.35 & 102.10 & 1.59 \\
\hline
\end{tabular}

$*, * *$ indicated at $5 \%$ and $1 \%$ level of significance, $\mathrm{KW}=$ Kernel Weight.

The desirable significant SCA effects observed for different characters were exhibited by the crosses involved high $\times$ high, high $\times$ average, average $\times$ average or high $\times$ low and low $\times$ low general combining parents. High SCA effects manifested by different crosses were of good combiner parents might be attributed to sizeable additive $\times$ additive gene action. The high $\times$ low combinations, besides expressing the favorable additive effect of the high parent, manifested some complementary gene interaction effects with a higher SCA. An 
appreciable amount of the SCA effects expressed by low $\times$ low crosses might be ascribed to dominance $\times$ dominance type of non-allelic gene action produced over dominance and are non-fixable. It appears that superior performance of most hybrids may be largely due to epistatic interaction. The SCA effects of the crosses exhibited no specific trends in cross combinations between parents having high, medium and low gca effects. Any combination among the parents may produce hybrid vigour over the parents which might be due to dominant, over dominant or epistatic gene action. So, the crosses which showing desirable SCA effects can be used in future breeding program.

\section{Heterosis}

The standard heterosis expressed by the $\mathrm{F}_{1}$ hybrids over the two standard checks namely NK40 and 900MG (commercial hybrid)) for different characters are presented in Tables 5 and 6 . The percent of heterosis in $F_{1}$ hybrids varied from character to character or from cross to cross.

\section{Days to tasseling and days to silking}

Days to tasseling and silking determine the earliness of flowering of the hybrid. Negative heterosis is desirable for these characters. Considering commercial hybrid NK40 as a check 4 crosses showed significant negative heterosis for days to tasseling and ranged from -0.506 to $14.04 \%$. For days to silking, 3 crosses also showed significant negative heterosis and ranged from -4.37 to 14.97 (Table 5). When we considered 900MG as check, 4 crosses exhibited significant negative heterosis for $50 \%$ tassel date which ranged were -6.63 to 12.15 . For $50 \%$ silk date 4 crosses showed significant negative heterosis out of 21 and ranged were 7.41 to 13.23 (Table 6).

\section{Plant height and ear height}

Negative heterosis is desirable for plant height and ear height which helps for developing short statured plant leads to less lodging. Considering commercial hybrid NK40 as a check 11 crosses exhibited significant negative heterosis for plant height indicate dwarfness of the hybrids (Table 5). Some crosses also showed significant positive heterosis for this trait. For ear height, 5 crosses showed significant negative heterosis others are positive (Table 5).

To compare with check variety $900 \mathrm{MG}, 8$ crosses performed significant negative heterosis for plant height. For ear height, 11 crosses expressed significant negative heterosis.

\section{Days to maturity}

Negative heterosis is also desirable for days to maturity which helps for adjusting cropping pattern. Considering commercial hybrid NK40 as a check 6 crosses 
expressed significant negative heterosis (Table 5). Compare with 900MG as check, 12 crosses expressed significant negative heterosis for the trait (Table 6).

Table 5. Percent heterosis over the check variety NK40 for different characters in $7 \times 7$ diallel crosses of maize

\begin{tabular}{|c|c|c|c|c|c|c|c|}
\hline $\begin{array}{l}\text { Cross/ } \\
\text { Hybrids }\end{array}$ & $\begin{array}{c}\text { Days to } \\
\text { tassel }\end{array}$ & $\begin{array}{c}\text { Days to } \\
\text { silk }\end{array}$ & $\begin{array}{c}\text { Plant ht. } \\
(\mathrm{cm})\end{array}$ & $\begin{array}{c}\text { Ear ht. } \\
(\mathrm{cm})\end{array}$ & \begin{tabular}{|l|} 
Days to \\
maturity
\end{tabular} & $\begin{array}{c}1000-\mathrm{KW} \\
(\mathrm{g})\end{array}$ & $\begin{array}{l}\text { Yield } \\
(\mathrm{t} / \mathrm{h})\end{array}$ \\
\hline $\mathrm{P}_{1} \times \mathrm{P}_{2}$ & $8 * *$ & $7.10 * *$ & $-6.67 * *$ & $-4.00 * *$ & $1.72 * *$ & -25.30 & 5.46 \\
\hline $\mathrm{P}_{1} \times \mathrm{P}_{3}$ & $3 * *$ & $4.92 * *$ & $-3.81^{*}$ & $-10.50^{* *}$ & $-1.03^{* *}$ & -27.71 & $-29.44 * *$ \\
\hline $\mathrm{P}_{1} \times \mathrm{P}_{4}$ & $-3.93 * *$ & $-2.73 *$ & $-12.86^{* *}$ & -1.00 & $-1.03 * *$ & -18.07 & $-19.87 * *$ \\
\hline $\mathrm{P}_{1} \times \mathrm{P}_{5}$ & $6.74 * *$ & $7.65 * *$ & $-9.05 * *$ & -1.00 & $-1.37 * *$ & -39.76 & $-51.39 * *$ \\
\hline $\mathrm{P}_{1} \times \mathrm{P}_{6}$ & $7.87 * *$ & $9.29 * *$ & 2.14 & $6.00 * *$ & $1.72 * *$ & -26.51 & $-20.68 * *$ \\
\hline $\mathrm{P}_{1} \times \mathrm{P}_{7}$ & $5.62 * *$ & $6.56 * *$ & $-5.00 * *$ & 2.50 & $2.06^{* *}$ & -28.92 & $-29.69 * *$ \\
\hline $\mathrm{P}_{2} \times \mathrm{P}_{3}$ & $3.93 * *$ & $4.37 * *$ & & $12.00 * *$ & $1.03 * *$ & -27.71 & $9.87 *$ \\
\hline $\mathrm{P}_{2} \times \mathrm{P}_{4}$ & $-4.49 * *$ & $-3.83 * *$ & $-15.24 * *$ & $-6.50 * *$ & -0.69 & -13.25 & $-11.56 * *$ \\
\hline $\mathrm{P}_{2} \times \mathrm{P}_{5}$ & $5.62 * *$ & $6.01 * *$ & $9.05^{* *}$ & $12.00^{* *}$ & $2.41 * *$ & -21.69 & $-23.19^{* *}$ \\
\hline $\mathrm{P}_{2} \times \mathrm{P}_{6}$ & $6.74 * *$ & $8.20 * *$ & -3.10 & $4.00 *$ & $2.06^{* *}$ & -14.46 & -3.57 \\
\hline $\mathrm{P}_{2} \times \mathrm{P}_{7}$ & $14.04 * *$ & $16.94 * *$ & $-13.57 * *$ & & & -8.43 & $-50.76 * *$ \\
\hline $\mathrm{P}_{3} \times \mathrm{P}_{4}$ & $-5.06 * *$ & $-4.37 * *$ & -1.19 & $-9.00 * *$ & $-1.03 * *$ & -13.25 & -6.51 \\
\hline $\mathrm{P}_{3} \times \mathrm{P}_{5}$ & $4.49 * *$ & $5.46^{* *}$ & $10.24 * *$ & $10.00^{* *}$ & -0.34 & -43.37 & $-30.64 * *$ \\
\hline $\mathrm{P}_{3} \times \mathrm{P}_{6}$ & $5.06^{* *}$ & $7.10^{* *}$ & $-8.57 * *$ & -0.50 & $.72 * *$ & -30.12 & 5.23 \\
\hline $\mathrm{P}_{3} \times \mathrm{P}_{7}$ & 0.00 & 1.64 & & & & & $-23.73 * *$ \\
\hline $\mathrm{P}_{4} \times \mathrm{P}_{5}$ & 0.56 & 2.19 & 0.95 & & $-2.41 * *$ & -13.25 & $-9.02 *$ \\
\hline $\mathrm{P}_{4} \times \mathrm{P}_{6}$ & $-2.25^{*}$ & -1.09 & $-14.29 * *$ & $3.90^{*}$ & -0.34 & -32.53 & $12.43 * *$ \\
\hline $\mathrm{P}_{4} \times \mathrm{P}_{7}$ & 1.12 & 2.19 & 2.14 & -1.30 & 0.34 & -20.48 & $-9.39^{*}$ \\
\hline $\mathrm{P}_{5} \times \mathrm{P}_{6}$ & $7.87 * *$ & $9.29 * *$ & $-11.90 * *$ & 1.00 & $1.72 * *$ & -25.30 & $-8.63^{*}$ \\
\hline $\mathrm{P}_{5} \times \mathrm{P}_{7}$ & $2.81^{*}$ & $2.73^{*}$ & -4.52 & $6.50 * *$ & -0.69 & -28.92 & $-18.68 * *$ \\
\hline $\mathrm{P}_{6} \times \mathrm{P}_{7}$ & $4.49 * *$ & $5.46 * *$ & $-13.10 * *$ & -2.50 & $2.06 * *$ & -27.71 & $10.89^{*}$ \\
\hline Mean & 3.40 & 4.53 & -4.26 & 1.03 & 0.41 & -24.73 & -14.42 \\
\hline Minimum & -5.06 & -4.37 & -15.24 & -10.50 & -2.41 & -43.37 & -51.39 \\
\hline Maximum & 14.04 & 16.94 & 10.24 & 12.00 & 2.41 & 8.43 & 12.43 \\
\hline Std. Error & 1.03 & 1.09 & & & 0.34 & 1.97 & 3.98 \\
\hline $\mathrm{CD}_{(0.05)}$ & 2.14 & 2.28 & 3.61 & 3.03 & 0.71 & 4.11 & 8.31 \\
\hline $\mathrm{CD}_{(0.01)}$ & 2.92 & 3.10 & 4.93 & 4.14 & 0.97 & 5.60 & 11.34 \\
\hline
\end{tabular}

$*, * *$ indicated at $5 \%$ and $1 \%$ level of significance, $\mathrm{KW}=$ Kernel Weight. 


\section{Kernel yield}

When standard commercial check was NK40, the percent heterosis for kernel yield varied from -51.39 to $12.53 \%$. It showed that among the $21 \mathrm{~F}_{1} \mathrm{~s}, 3$ crosses exhibited significant positive heterosis for kernel yield (Table 5). The highest heterosis $12.43 \%$ was exhibited by the cross $\mathrm{P}_{4} \times \mathrm{P}_{6}$ followed by $\mathrm{P}_{6} \times \mathrm{P}_{7}(10.89 \%)$ and $\mathrm{P}_{2} \times \mathrm{P}_{3}(9.87 \%)$.

Table 6. Percent heterosis over the check variety 900MG for different characters in $7 \times 7$ diallel cross of maize

\begin{tabular}{|c|c|c|c|c|c|c|c|}
\hline $\begin{array}{l}\text { Cross/ } \\
\text { Hybrids }\end{array}$ & \begin{tabular}{|c|} 
Days to \\
tassel
\end{tabular} & $\begin{array}{l}\text { Days to } \\
\text { silk }\end{array}$ & \begin{tabular}{|c|} 
Plant ht. \\
(cm)
\end{tabular} & $\begin{array}{l}\text { Ear ht. } \\
(\mathrm{cm})\end{array}$ & $\begin{array}{l}\text { Days to } \\
\text { maturity }\end{array}$ & $\begin{array}{c}1000-\mathrm{KW} \\
(\mathrm{g})\end{array}$ & $\begin{array}{l}\text { Yield } \\
(\mathrm{t} / \mathrm{h})\end{array}$ \\
\hline $\mathrm{P}_{1} \times \mathrm{P}_{2}$ & $4.42 * *$ & $3.70 * *$ & -2.97 & $-9.0 * * 0$ & -0.34 & $-16.22 * *$ & 0.38 \\
\hline $\mathrm{P}_{1} \times \mathrm{P}_{3}$ & $2.21^{*}$ & 1.59 & 0.00 & $-15.17 * *$ & $-3.03 * *$ & $-18.92 * *$ & $-32.84 * *$ \\
\hline $\mathrm{P}_{1} \times \mathrm{P}_{4}$ & $-5.52 * *$ & $-5.82 * *$ & $-9.41 * *$ & $-6.16^{* *}$ & $-3.03 * *$ & $-8.11 * *$ & $-23.73 * *$ \\
\hline $\mathrm{P}_{1} \times \mathrm{P}_{5}$ & $4.97 * *$ & $4.23 * *$ & $-5.45 * *$ & $-6.16^{* *}$ & $-3.37 * *$ & $-32.43 * *$ & $-53.73 * *$ \\
\hline $\mathrm{P}_{1} \times \mathrm{P}_{6}$ & $6.08^{* *}$ & $5.82 * *$ & $6.19^{* *}$ & 0.47 & -0.34 & $-17.57 * *$ & $-24.50 * *$ \\
\hline $\mathrm{P}_{1} \times \mathrm{P}_{7}$ & $3.87 * *$ & $3.17 * *$ & -1.24 & -2.84 & 0.00 & $-20.27 * *$ & $-33.08 * *$ \\
\hline $\mathrm{P}_{2} \times \mathrm{P}_{3}$ & $2.21 *$ & 1.06 & $12.87 * *$ & $6.16 * *$ & $-1.01 * *$ & $-18.92 * *$ & 4.57 \\
\hline $\mathrm{P}_{2} \times \mathrm{P}_{4}$ & $-6.08 * *$ & $-6.88 * *$ & $-11.88 * *$ & $-11.37 * *$ & -2.6 & -2.7 & $-15.82 * *$ \\
\hline $\mathrm{P}_{2} \times \mathrm{P}_{5}$ & $3.87 * *$ & $2.65^{*}$ & $13.37^{* *}$ & 6.16 & 0.34 & $-12.16^{* *}$ & $-26.89 * *$ \\
\hline $\mathrm{P}_{2} \times \mathrm{P}_{6}$ & $4.97 * *$ & $4.76^{* *}$ & 0.74 & -1.42 & 0.00 & -4.05 & $-8.22 *$ \\
\hline $\mathrm{P}_{2} \times \mathrm{P}_{7}$ & $12.15^{* *}$ & $13.23^{* *}$ & $-10.15^{* *}$ & $-14.22 * *$ & 0.34 & 2.7 & $-53.13 * *$ \\
\hline $\mathrm{P}_{3} \times \mathrm{P}_{4}$ & $-6.63 * *$ & $-7.41 * *$ & 2.72 & $-13.74 * *$ & $-3.03 * *$ & -2.7 & $-11.02 * *$ \\
\hline $\mathrm{P}_{3} \times \mathrm{P}_{5}$ & $2.76^{*}$ & 2.12 & $14.60^{* *}$ & $4.27 * *$ & $-2.36 * *$ & $-36.49 * *$ & $-33.99 * *$ \\
\hline $\mathrm{P}_{3} \times \mathrm{P}_{6}$ & $3.31 * *$ & $3.70 * *$ & $-4.95 *$ & $-5.69 * *$ & -0.34 & $-21.62 * *$ & 0.16 \\
\hline $\mathrm{P}_{3} \times \mathrm{P}_{7}$ & -1.66 & -1.59 & $4.21 *$ & -2.84 & $-3.70 * *$ & $-24.32 * *$ & $-27.40 * *$ \\
\hline $\mathrm{P}_{4} \times \mathrm{P}_{5}$ & -1.10 & -1.06 & $4.95^{*}$ & 1.42 & $-4.38 * *$ & -2.7 & $-13.41 * *$ \\
\hline $\mathrm{P}_{4} \times \mathrm{P}_{6}$ & $-3.87 * *$ & $-4.23 * *$ & $-10.89 * *$ & -1.52 & $-2.36^{* *}$ & -2.7 & 7.01 \\
\hline $\mathrm{P}_{4} \times \mathrm{P}_{7}$ & & -1.06 & $6.19 *$ & $-6.45^{* *}$ & $-1.68 * *$ & $-10.81 * *$ & $-13.75^{* *}$ \\
\hline $\mathrm{P}_{5} \times \mathrm{P}_{6}$ & $6.08 * *$ & $5.82 * *$ & $-8.42 * *$ & $-4.27 * *$ & -0.34 & $-16.22 * *$ & $-13.03 * *$ \\
\hline $\mathrm{P}_{5} \times \mathrm{P}_{7}$ & 1.10 & -0.53 & -0.74 & 0.95 & $-2.69 * *$ & $-20.27 * *$ & $-22.59 * *$ \\
\hline $\mathrm{P}_{6} \times \mathrm{P}_{7}$ & $2.76^{*}$ & 2.12 & $-9.65 * *$ & $-7.58^{* *}$ & 0.00 & $-18.92 * *$ & 5.55 \\
\hline Mean & 1.68 & 1.21 & -0.47 & -4.24 & -1.62 & -15.57 & -18.55 \\
\hline Minimum & -6.63 & -7.41 & -11.88 & -15.17 & -4.38 & -36.49 & -53.73 \\
\hline Maximum & 12.15 & 13.23 & 14.60 & 6.16 & 0.34 & 2.7 & 7.01 \\
\hline Std. Error & 1.01 & 1.06 & 1.80 & 1.38 & 0.33 & 2.21 & 3.79 \\
\hline $\mathrm{CD}_{(0.05)}$ & 2.11 & 2.20 & 3.75 & 2.87 & 0.70 & 4.61 & 7.91 \\
\hline $\mathrm{CD}_{(0.01)}$ & 2.88 & 3.01 & 5.12 & 3.92 & 0.95 & 6.28 & 10.79 \\
\hline
\end{tabular}

$*, * *$ indicated at $5 \%$ and $1 \%$ level of significance, $\mathrm{KW}=$ Kernel Weight. 
When estimated with 900MG as check, the percent heterosis for kernel yield varied from -53.73 to $7.01 \%$. It showed that among the $21 \mathrm{~F}_{1} \mathrm{~s}$, none crosses exhibited significant positive heterosis for kernel yield (Table 6). The highest heterosis $7.01 \%$ was exhibited by the cross $\mathrm{P}_{4} \mathrm{xP}_{6}$ followed by $\mathrm{P}_{6} \mathrm{xP}_{7}(5.5 \%)$ and $\mathrm{P}_{2} \times \mathrm{P}_{3}(4.57 \%)$. Debnath (1988) and Roy et al., (1998) reported 43.05 to $96.74 \%$ and -16.42 to $71.82 \%$ heterobeltiosis.

\section{Conclusion}

From the study, the parents like $\mathrm{P}_{1}$ (for early flowering and short duration), $\mathrm{P}_{4}$ (for yield, early flowering, short plant and ear height), $\mathrm{P}_{5}$ (short duration) and $\mathrm{P}_{6}$ (for yield) may be used as donor for combining high yield with desirable traits. The crosses $\left(\mathrm{P}_{2} \times \mathrm{P}_{3}, \mathrm{P}_{4} \times \mathrm{P}_{6}\right.$ and $\left.\mathrm{P}_{6} \times \mathrm{P}_{7}\right)$ showed the highest heterosis for yield compared to the checks (NK40 and 900MG). The cross combinations manifested significant high SCA effects coupled with per se performance and could be more rewarding in a hybrid breeding program after intensive investigation at different agro ecological zones.

\section{References}

Beck, D. L., S. K. Vasal and J. Crossa. 1990. Heterosis and combing ability of cimmyt, tropical early and intermediate maturity maize (Zea mays L.) germplasm Maydica, 35: 279-285.

CIMMYT. 2008. Achievements of the Bangladesh-CIMMYT partnership for agricultural research and development. CIMMYT-Bangladesh, Banani, Dhaka.

Charlesworth, D. and J. H. Willis. 2009. "The genetics of inbreeding depression". Nature Reviews Genetics. 10(11): 783-796.

Debnath, S.C. 1988. Heterosis in maize for grain yield, maturity characters, plant height and ear height. Bangladesh J. Agri. Res. 13: 17-21.

Debnath, S.C. and K.R. Sarker. 1990. Combining ability analysis of grain yield and some of its attributes in maize (Zea mays L.). Indian J. Genet. 50: 57-61.

Derera, J. P., Tongoona, B.S. Vivek and M.D. Laing. 2007. Gene action controlling grain yield and secondary traits in southern African maize hybrids under drought and nondrought environments. Euphytica. 162: 411-422.

Griffing, B. 1956. Concept of general and specific combining ability in relation to diallel crossing systems. Aust. J. Biol. Sci. 9: 463-493.

Hussain, S.A., M. Amiruzzaman and Z. Hossain. 2003. Combining ability estimates in maize. Bangladesh. J. Agril. Res. 28: 435-440.

Khotyleva, L.V., L.S. Tarulina and I. Kapusta. 1986. Genetic interpretations of the combining ability of maize lines for quantitative character following use of different crossing systems. Biologya. 8: 78-82.

Lee, M.H. 1987. Studies on the combining ability for silage yield and major agronomic characters of corn. Korean J. Crop Sci. 32: 201-207. 
Mathur, R.K. and S.K. Bhatnagar. 1995. Partial diallel cross analysis for grain yield and its component characters in maize (Zea mays L.). Ann. Agric. Res. 16: 324-329.

Narro, L., S. Pandey, J., Crossa, C.D., Leon and F. Salazar. 2003. Using line $\times$ tester interaction for the formation of yellow maize synthetics tolerance to acid soils. Crop Sci. 43: 1717-1728.

Pal, A. K. and S. H. Prodhan. 1994. Combining ability analysis of grain yield and oil content along with some other attributes in maize (Zea mays L.). Indian J. Genet. 54:376-380.

Rokadia, P. and S.K. Kaushik. 2005. Exploitation of combining ability for heterosis in maize (Zea mays L.). In: Pixley, K. and S.H. Zhang (ed). Proc. 9th Asian Reg. Maize Workshop. Beijing, China, September 5-9, Pp. 89-91.

Roy, N.C., S.U. Ahmed., S.A. Hussain and M.M. Hoque. 1998. Heterosis and combining ability analysis in maize (Zea mays L.). Bangladesh J. Pl. Breed. Genet. 11: 35-41.

Sharief, A. E., S. E. El-Kalla, H. E. Gado and H. A. E. Abo-Yousef, 2009. Heterosis in yellow maize. Aust. J. Crop Sci. 3: 146-154.

Singh, P.K. and N. Kumar. 2008. Identification of parents and experimental single cross hybrids in maize (Zea mays L.). Book of Abstracts. The $10^{\text {th }}$ Asian Reg. Maize Workshop. Makassar, Indonesia, October 20-23, 2008. $61 \mathrm{P}$.

Singh, S.P. and H.N. Singh. 1979. Genetic divergence in Okra (Abelmoxhus esculentus L. Moerch). Indian J. Hort. 36: 166-170.

Singh, R.K. and P.K. Singh. 1994. A manual on Genetics and Plant Breeding. Experimental Techniques. Kalyani Publs. Ludiana, New Delhi. Pp. 99-107.

Singh, G., M. Singh and K.R. Dhiman. 1995. Genetic analysis of maize (Zea mays L.) in Sikkim. Indian J. Agri. Sci. 65: 293-294.

Vasal, S.K. 1998. Hybrid maize technology: Challenges and expanding possibilities for research in the next century. In: Vasal, S.K., C.F. Gonzalez and F. Xingming (ed). Proc. 7th Asian Reg. Maize Workshop. Los Banos, Philippines, February 23-27, Pp. 58-62.

Xingming, F., J. Tan, Z. Chen and J. Yang. 2002. Combining ability and heterotic grouping of ten temperate, tropical and subtropical quality protein maize. In: Srinivasan, G., P.H. Zaidi, B.N. Prasanna, F.C. Gonzalez and K. Lesnick (ed). Proc. 8th Asian Reg. Maize Workshop. Bangkok, Thailand, August 5-8, Pp. 10-18.

Zelleke, H. 2000. Combining ability for grain yield and other agronomic characters in inbred lines of maize (Zea mays L.). Indian J. Genet. 60: 63-70. 